\title{
VISUALIZATION AND ANALYSIS OF CELLULAR \& TWITTER DATA USING QGIS
}

\author{
Badatala Sowkhya $^{\mathrm{a}}$, Salavatore Amaduzzi ${ }^{\mathrm{b}}$, Darshana Raawal ${ }^{\mathrm{c}}$ \\ ${ }^{a}$ CEPT University, Gujarat, India, sowkhyab@gmail.com

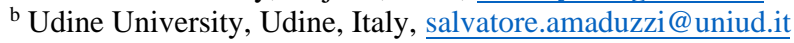 \\ ${ }^{\mathrm{c}}$ CEPT University, Gujarat, India. rawalnet@yahoo.com
}

\section{Commission IV, WG IV/4}

KEY WORDS: QGIS, Twitter feed, Cellular data, Origin Destination Matrices, Thematic maps.

\begin{abstract}
:
The study is to understand individual presence and movement in Friuli Venezia Giulia region. It is important for tourism planning, hazard management, business marketing, implementing government lifetime policies and benefit. The aim of this study is achieved by advanced web 2.0 applications. We need real time and geo-located data to monitor the inflow of tourist and to come up with effective promoting and benefiting plans for tourism, the evacuation and mitigation strategies during hazards to protect social life and environment with less infrastructure damage, marketing plans for advertising or selling of products. Despite wide spread success in predicting specific aspects of human behavior by social media information, a little attention is given to twitter and cell phone data. Accessibility to detailed human movements with fine spatial and temporal granularity is challenging due to confidentiality and safety reasons. With rapid development of web2.0 applications people can post about events, share opinion and emotions online. Using twitter data, how short term travelers, such as tourists, can be recognized and how their travel pattern can be analyzed. Study of finding tourist dynamics such as arriving and outgoing of tourist, sum of trips, sum of days and night spent, number of unique visitors, country of residence, main destination, secondary destination, transits pass through, repeat visits are achieved using CDR (call detail records) and DDR (data detail records).
\end{abstract}

\section{INTRODUCTION}

Understanding human movement within a geographic area i.e., national to international is crucial in various domains and applications. This understanding helps to play an important role in urban planning, transportation, emergency relief, marketing strategies, etc. This is achievable due to improvement in technologies to fetch real time and reliable data for research. Accessibility to detailed human movements with fine spatial and temporal granularity is challenging due to confidentiality and safety reasons. With rapid development of web2.0 applications people are able to post about events, share opinion and emotions online. Social media covers wide variety of topics from something as simple as some products events and services to more complex issues related with finance, culture, politics, religion, food, epidemics, famine etc.,. Twitter is one of the most popular social network website. Twitter's speed and ease of publication have made it an important communication medium for people of all lifestyles. It has also been used to recognize short-term travellers and to analyse their travel using Twitter data (Shamanth Kumar, 2013)

Other ways to study human movement is through cell phone network. Mobile phone data represents movement of the network user. In the context of mobile networks, it is described as when a mobile used outside the range of its home network and connects to another cell network (Rein Ahas, 2014) For example subscriber travelling beyond company transmitter range; their mobile would spontaneously hop onto alternative phone service and is done with the help of subscriber identity in the visited network. Study of finding tourist dynamics such as arriving and outgoing of tourist, sum of trips, sum of days and night spent, number of unique visitors, country of residence, main destination, secondary destination, transits pass through, repeat visits are achieved using CDR (call detail records) and DDR (data detail records). Some of the applications achieved by mobile positioned data are (Rein Ahas, 2014)

- tourism business applications,

- event monitoring ("Mobile Landscapes: Graz, Austria in Real Time", directed by C. Ratti, A. Shevtsuk et al (MIT\&Ratti Associates) in 2005.

- the experiment "Real Time Rome", conducted by MIT to study a Madonna concert in Rome and

- football matches in Milan analysed by the Frauenhofer Institute in 2008), Transport research, Emergency and safety solutions.

\subsection{Problem Statement:}

To understand the individual presence and movement in Friuli Venezia Giulia region.

\subsection{Research Questions:}

- How many individuals are present in certain area at specific time?

- Where do they come from?

- Where will they go from one place to another?

- How the presence and movement of individuals change over time?

- How the trend change for different nationalities?

\subsection{Aim and Objectives:}

The aim of this study is to analyse patterns, trends \& associations of human behaviour and their interactions. 


\section{Objectives:}

Patterns: How the presence and movement of individuals vary in the study area.

Trend: How the patterns vary over time.

Association: How various case study and their amalgamation with social media affect the presence and movement of individuals.

\subsection{Study Area:}

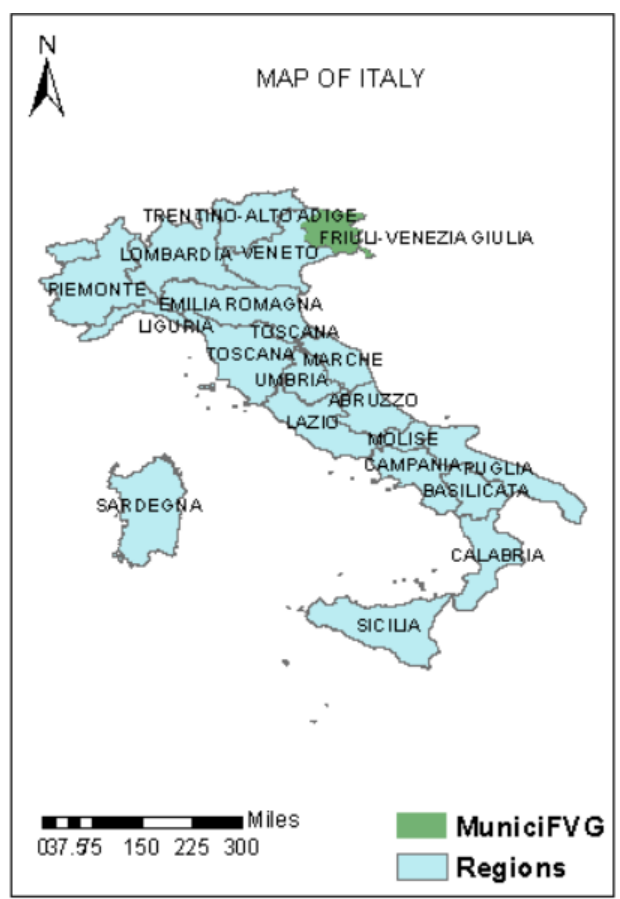

Figure 1-4-1 Map of Italy

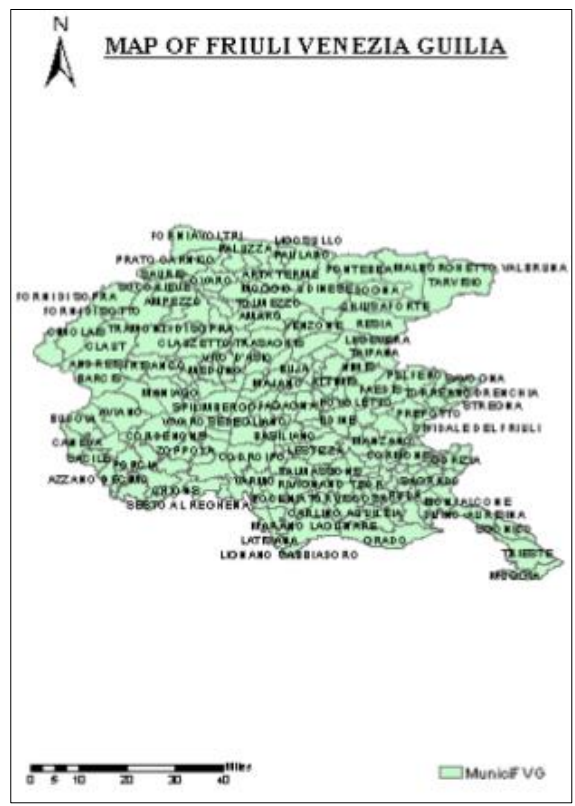

Figure 1-4-2 Map of Friuli Venezia Giulia

Fig 1-4-1 and 1-4-2 show map of Italy and study region Friuli Venezia Giulia respectively. Italy is a unitary parliamentary republic country in Europe, with a long Mediterranean coastline. It is bordering with Vatican City, San Marino, France, Switzerland, Slovenia and Austria (Algorithm, n.d.). It consist an area of $301,338 \mathrm{~km}^{2}$, has various temperate seasonal and Mediterranean environment. It is the Fourth populated region of European Union Member state with 61 million inhabitants and 20 regions. Rome is the capital city.

Friuli Venezia Giulia is located in North East of Italy region. Its geographical coordinates are $46022^{\prime} \mathrm{N}$ and $13010^{\prime} \mathrm{E}$. It is bordering with Adriatic Sea, Slovenia and Austria. It is one of the five autonomous regions with special statute. It has an area of $7858 \mathrm{~km}^{2}$ with 1.2 million inhabitants (Friuli Venezia Giulia, n.d.). It has a natural opening to the sea for many central European countries. It encompasses the historical geographical region of Friuli and small historical region of Venezia Giulia. It has sharp peaked dolomite mountains and wine yards producing white wine. Trieste is the capital of Friuli region.

\subsection{Back Ground:}

Use of Mobile Positioning Data: Extensive use of mobile positioning data is used by European countries. It tries to make an effort to explain the art of using cellular data in the study of various domains. It describes wide range of applications on mobile based data. The research applications that can be done by using mobile positioning data are monitoring real time events, business applications and transportation, emergency and relief solutions. Many important initiatives are made in the study of traffic and travel behaviour. All over the world TomTom HD, traffic uses mobile positioning data as their primary key for intelligent traffic guidance system (Rein Ahas, 2014) It mentions the importance of transparency in using such data source. It also mention about emergency solutions with the help of cell phone data. There are number of case studies, which show increasing interest in commercial value of the data in various domains ${ }^{[4]}$ The initiatives are playing an important role in urban studies, transportation, and academia and advertising market. It explains the methodology for collecting and usage of the data. In most of the cases, passive positioning data is used to describe country level statistics. In 2005 - 2006, "Mobile Landscape: Graz, Austria in Real Time" was developed to track human behaviour based on mobile positioning data as simultaneously users cell phones are pinged to know their precise location at given time. It considers mobile information for time dependent population distribution and motion patterns (Rein Ahas, 2014) The European commission also talks about urban planning to actively analyse, strategies and accomplish the urban atmosphere. Governing bodies to achieve the above-mentioned applications have adopted this methodology.

Use of Twitter Data: Twitter feeds usually contain normal text, hash tags, username, tweet location, user creation time and date. These tweets can be accessed either streaming online into application or downloading the tweets by other sources. These hashtag text talks about particular event or scenario that are geotagged and is easy to work. This data majorly used to know individual associations on social media by calculating density of tweets. It explain how social media can facilitate and enhance transportation planning, management and operation. Social networking sites such as Foursquare, Flicker, Twitter, Facebook, Instagram and YouTube are also been used to understand the geographical location of the user. One of the widely used applications of twitter feed is to facilitate response and relief operations during emergency by crowdsourcing. User spatial and temporal aspect can be stalked by check in option available in application, which allows social media user to share their locations. Later a system was developed based on temporal properties of consumer movements using location-based data. Feasibility study of sensing traffic incidents from tweets suggested a way to manage and control traffic incidents. To study individual movement and user activity patterns researches were 
conducted on location-based data collected from public networking services. These tweets are helpful in studying the role of social media in search engine results when a travel related topic searched in the search engine which verify the flicker database, that are geo-tagged. It reduces the effort of text mining. It helps in recommending personalized suggestions for tourist visiting preferable places in new place by analysing users travel experience and historical data posted on social media by sharing geotagged photos on Flicker (Rein Ahas, 2014). These geotagged photos are used in understanding spatiotemporal behaviour of individuals. Geo tagged photos helped in developing system that can automatically construct travel itineraries for tourist.

\section{METHODOLOGY}

\subsection{Data Used:}

Study region is divided into cell of $150 * 150$ meter to obtain cellular data. Cell phone data provided presence of individuals per cell and origin destination matrix. Presence data is divided based on country of origin and Italians (residents, regular visitors, and occasional visitors). Data availability for the study is from March16 to September16.

Tweet feed were downloaded and contains user-id, coordinates, tweet time, text. Spatial and Non-spatial analysis were performed using open source software QGIS and Ms-office respectively. The data was provided by cellular network to academic for study purpose and data is maintained confidential.

\subsection{Data Flattening:}

Data flattening was required in order to perform calculations and analysis in deriving the output. All non-spatial data (excel files) were transformed into GIS format files using open source software and projected to "WGS 84 UTM 32 N".

\subsection{Algorithms Used:}

Algorithm is a self- contained sequence of actions to perform. It is an effective method, which is expressed with in finite amount of space and time and in well- defined formal language for calculating a function (Algorithm, n.d.)To reduce manual efforts and errors, simplified algorithms were created as per data type and output desired. Created models were used in generating maps on large-scale data. These models were useful in generating thematic maps of individual presence in each municipality and to generate flow lines of individual movement from one municipality to other.

\subsubsection{Generation of Thematic maps using algorithm:}

Fig.2-3-1 Show the flow of process to generate thematic maps. The data used in algorithm contains people presence in Friuli region (residents and foreigners of Italy) for six observation periods that is from March to September 2016 for a time interval of 4 hours ie., at $0 \mathrm{am}, 6 \mathrm{am} 12 \mathrm{pm}, 18 \mathrm{pm}$ and $24 \mathrm{pm}$. This model takes polygon (municipality of study area) and point file (presence of individuals) as inputs. It filters the data based on user specified expressions and the queried results merge with municipality shape file to visualize on map.

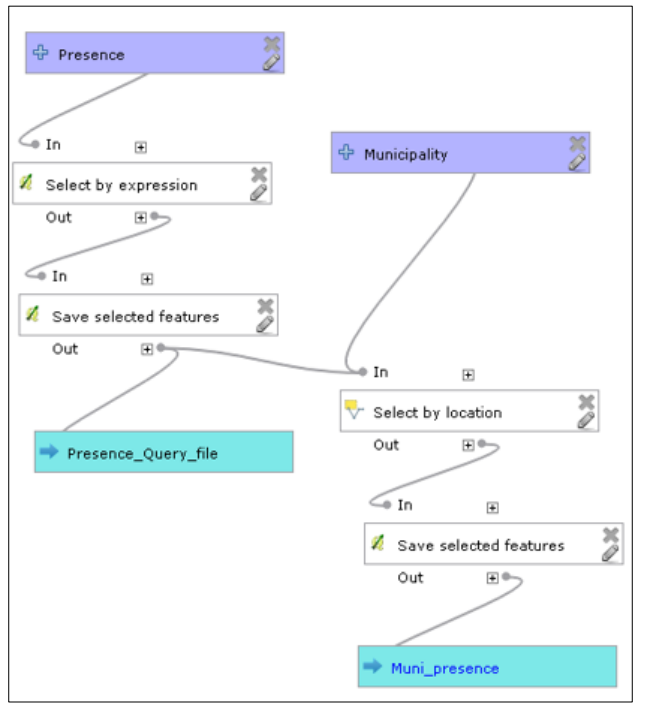

Figure 2-3-1 Model in QGIS to generate thematic maps

\subsubsection{Generation of Origin Destination flow lines} using algorithm:

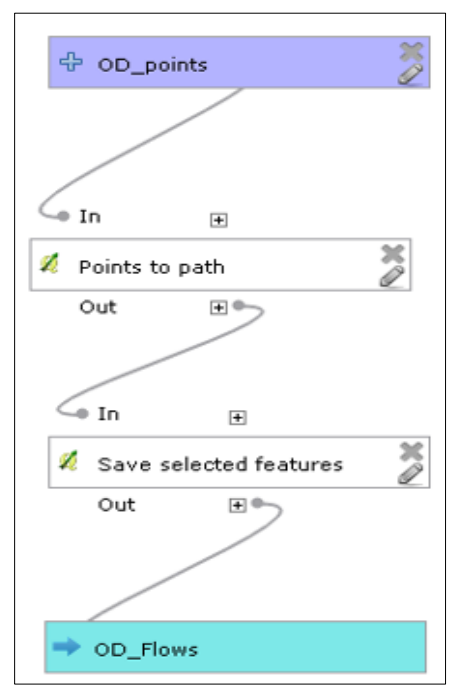

Figure 2-3-2 Model for OD flows
The model as shown in fig.2-3-2 generates origin destination flow lines, such as people movement for certain period of particular municipality. Flow line connect each point to their respective origin and destination. The model shown in fig. takes the input as origin destination points of each municipality. The output of this model can answer one of the research question where the individuals are from and where they are will go.

\subsubsection{Kernel Density- Tweet feed:}

To determine the density of people in municipality, kernel density is used. It calculates the density of features in a neighbourhood around those features. Conceptually, a smoothly curved surface is fitted over each point. The surface value is highest at the location of the point and diminishes with increasing distance from the point, reaching zero at the search radius distance from the point. Only a circular neighbourhood is possible. The volume under the surface equals the Population field value for the point, or one if NONE is specified (ESRI, n.d.)The density at each output raster cell is calculated by adding the values of all the kernel surfaces where they overlay the raster cell centre. Tool used to visualize the results on map and associate with other outputs. 


\section{CASE STUDIES}

\subsection{GRADO, ISLAND OF SUN:}

Grado is a town in the North Eastern part of Italy. It is a municipality of Friuli Venezia Giulia located on an island and adjacent peninsula of the Adriatic Sea between Venice and Trieste (GRADO, Beach, n.d.). It is mainly a fishing centre but today know as popular tourist destination. It is commonly known as L'Isola del Sole "The Sunny Island". It is famous as spa town because of its thermae and spa services. It has an area of $114 \mathrm{~km}^{2}$. Grado is a land of value, food products, culture and events, city of art and history. It is place where it has tourist throughout the year. To better understand the presence of Italians and foreigners, particular day based on weather report and time were selected. Very hot day ( $9^{\text {th }}$ August 16$)$, Rainy day (10 ${ }^{\text {th }}$ August16) and Sunny day ( $11^{\text {th }}$ August 16$)$ were opted and $12 \mathrm{pm}$ is preferred.

- To know places, people would likely to visit during very hot day, rainy and sunny day - thematic maps.

- To know people origin and destination points - Origin Destination Flows.

- To know density at the beach when compared to surrounding - Density tweets.

Maps are prepared separately for Italians and Foreigners.

\subsubsection{Thematic Maps - Italians \& Foreigners:}

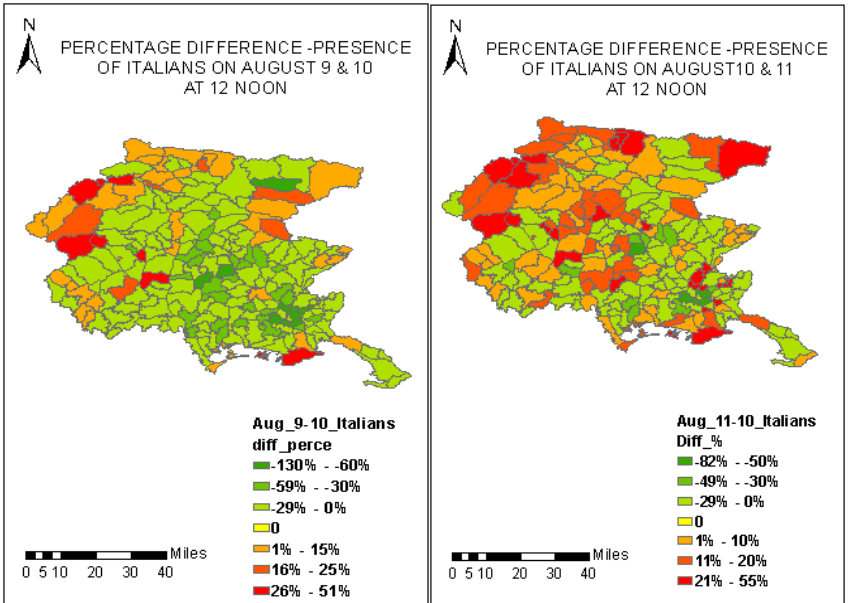

(a)

(b)

Figure 3.1.1-1 (a) Presence of Italians on August 9-10 @ 12pm (b) Presence of Italians on August 11-10 @ 12pm

- $\quad$ Above fig. 3.1.1-1a \& b are presence of Italians on August $9,10,11$ at $12 \mathrm{pm}$

- The percentages shown in above map explains the percentage difference of people present on corresponding dates. Difference of presence in percentage is calculated on August 9 and 10 to know at what percent the presence changes. Afternoon hour is considered because commonly people visit beach during that hour than other hours.

- $\quad$ Red zone represents presence of people on very sunny day $\left(9^{\text {th }}\right.$ August) while green zone represents presence of people on rainy day $\left(10^{\text {th }}\right.$ August)

- 09 August 2016, at 12 pm, which is very sunny day the percentage difference of people are from $12 \%$ to $51 \%$ (red color polygons),
- Grado presence percentage is $30 \%$; indicating presence is more on very sunny day. Andreis (50\%), Arba (40\%) and Barcis (43\%) has notable presence percentage on sunny day but not on rainy day.

- This high presence percentage is more in other places rather than Grado, due to these places contain monuments, churches, cathedrals, shrines.

- August $10^{\text {th }}$ rainy day- The presence in Grado is considerably less when compared with very sunny day.

- The higher percentage presence are observed in Martignacco (86\%), Dogna (77\%), Chiopris Viscone (86\%), Medea (130\%), Romans D'Isonzo (93\%), Visco (83\%), Villesse (108\%).

- These places are famous for Shopping malls, Churches, military museum, Historic sites, Architecture buildings, Ancient remains etc., Villesse has giant mall with Ika located, Medea - Ara Pacis, famous monument recalling fallen of all the wars, Aiello has more than 150 famous sundials.

- Sunny day- $11^{\text {th }}$ August16, Grado has percentage presence of $25 \%$. Higher than Grado presence is observed in Forni di Sopra (33\%), Paularo (27\%) and Barcis (47\%).

- These places are famous for mountain and hiking, caves, waterfalls and mountain hiking.

- Places with percentage difference from $15 \%$ to $18 \%$ are Malborghetto Valbruna (18\%), Claut (15\%), Buia (18\%), San Canzian D'Isonzo (18\%), Codroipo (16\%), Fagagna (17\%).

- These places has Battlefields cemeteries, Biking and Hiking Trails, Valleys, Canyon, Astronomical observatory, Villa Manin- noble villa back to $17^{\text {th }}$ century, Karst Spring park.

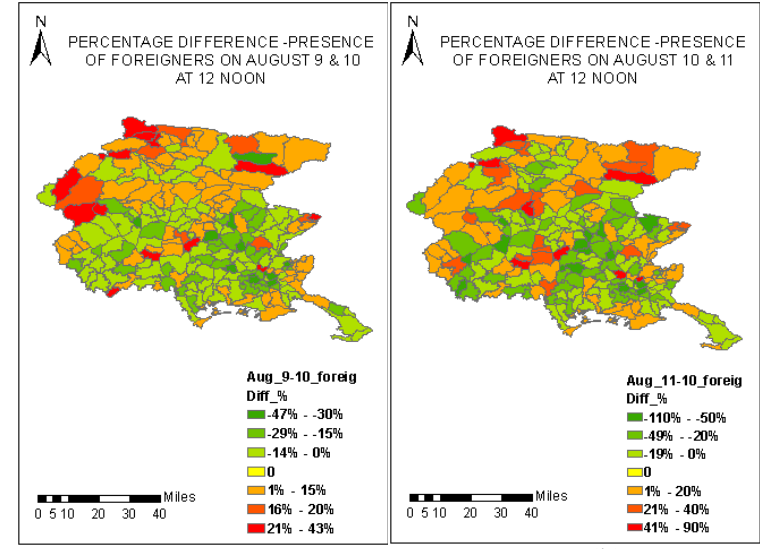

(a)

(b)

Figure 3.1.1- 2 (a) Presence of Foreigners on August 9-10 @ 12pm (b) Presence of Foreigners on August 11-10 @ 12pm

- $\quad$ Above fig. 3.1.1- 2 a \& b are presence of foreigners on (910) (10-11) of August at $12 \mathrm{pm}$.

- Foreigners: Very Sunny day August $9^{\text {th }}$ 2016, presence in Grado and Lignano Sabbiadoro ranges from 16 to $20 \%$.

- Percentage difference from 20 to $40 \%$, observed in Cimolais (26\%), Barcis (23\%), Forni Avoltri (36\%), Sauris (42\%), Rigolato $(22 \%)$, Chiusaforte $(30 \%)$, Mereto di Tomba (23\%), Valvasone Arzene (21\%), Pravisdomini (36\%), Chiopris Viscone (25\%).

- Rainy Day -10 August16, foreigner's percentage presence more than $30 \%$ are noticed in Aiello del Friuli (46\%), Villesse $(37 \%)$, Arba $(31 \%)$, Dogna $(30 \%)$, Reana del Roiale (45\%), Pradamano (33\%), Bicinicco (33\%), Martignacco (47\%), Romans D'isonzo (23\%). 
- Sunny day - 11 August 16 , presence in Grado is $18 \%$.

- Higher percentage difference other than Grado is observed in Medea (46\%), Trivignano Udinese (41\%), Mereto di tomba (51\%), Valvasone Arzene (47\%), Clauzetto (54\%), Chiusaforte (54\%), Forni Avoltri (53\%), Sauris (74\%).

- On rainy day, nearby Grado has foreigner's presence from 50 to $100 \%$ are observed in Villesse (56\%), Romans D'isonzo (51\%), Lestizza (57\%), Martignacco (109\%), Pasian di prato (88\%), Pulfero (62\%), Aiello del Friuli $(60 \%)$.

- Other places than Grado, Percentage difference from $20 \%$ to $40 \%$ are noticed in Ronchi del Legionari (31\%), Udine (26\%), San pier D'isonzo (29\%), Talmassons (29\%), Ruda (21\%), Remanzacco (33\%), Cervignano del Friuli (31\%), Bagnaria Arsa (39\%), Compolongo $\mathrm{Al}$ torre (35\%).

\subsubsection{Origin Destination flows for Italians:}
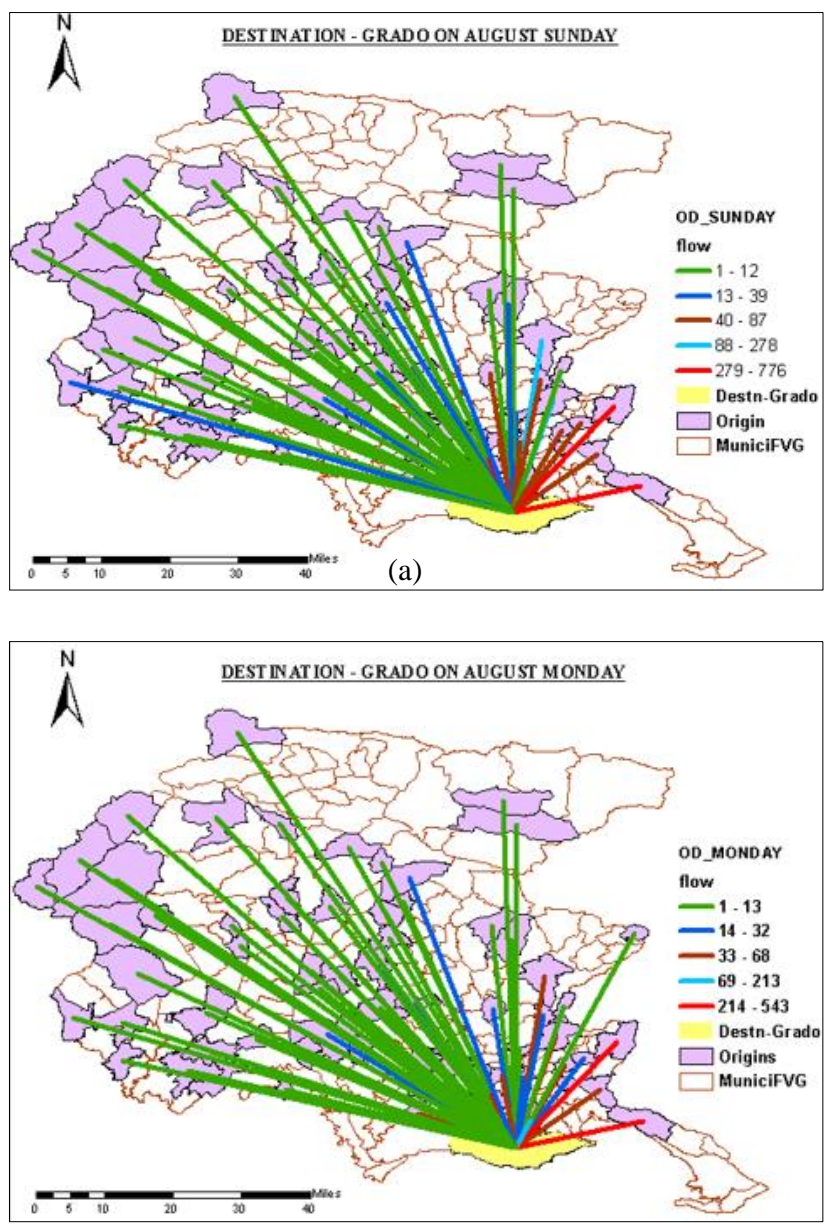

(b)

Figure 3.1.2-3 (a) \& (b) OD flows for Italians on August Sunday and Monday

- $\quad$ Fig 3.1.2-3 a \& b shown explains the following points.

- Flow count represents number of times to and fro movement happening. The flows of Italians from Sunday to Monday are 776 to 543 .

- The flow of Italians to Grado are decreasing from Sunday to Monday. Flow from 1 to 30 are from more places of west Friuli region and flow count is less due to distance from origin to destination is farther.
- Count flows to destination is more than 200 on south-east of Friuli Venezia Giulia due to less distance but from less places.

- Maximum flow above 250 to 780 are from Duino Aurisina and Gorizia.

\subsubsection{Origin Destination Flows for Foreigners:}

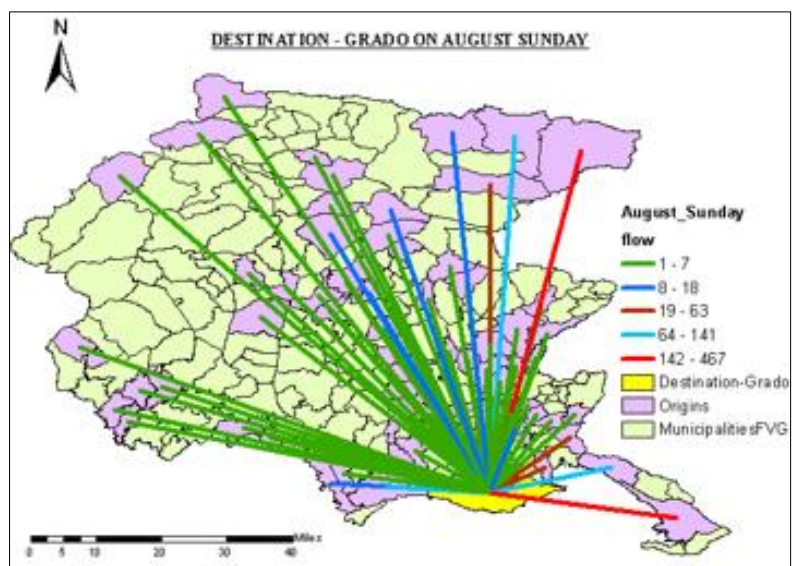

(a)

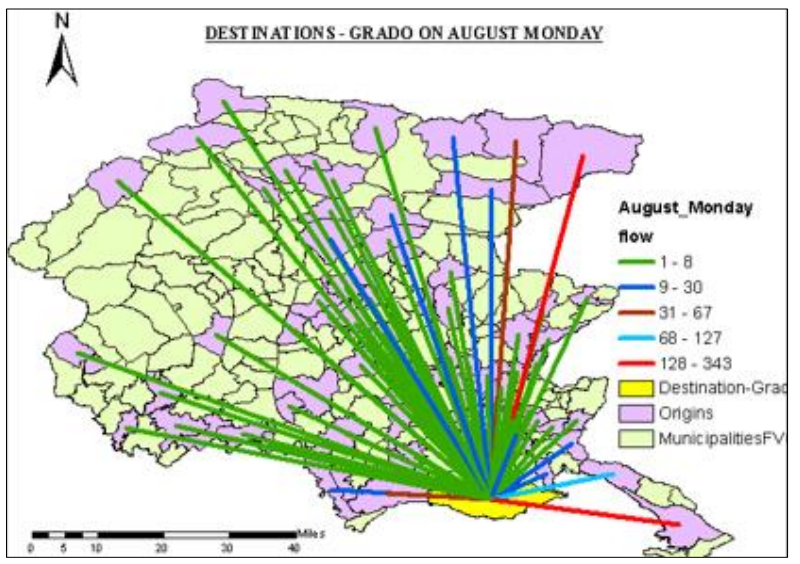

(b)

Figure 3.1.2-4 (a) \& (b) OD flows for Foreigners August Sunday and Monday

- The above fig.3.1.2-4 show flow count for foreigners. The Count flow on Sunday in Grado is 400. While on Monday, the flow is 350 .

- The foreigners are from North to South-West of the Friuli region. Maximum foreigners flow is observed in Treviso and Trieste because there is highway passing to FVG.

- While flows from 1 to 10 are observed in North and middle of Friuli region. It can also be assumed that people are present in that municipality the previous day and they are moving the next day.

\subsubsection{Tweet - Density Maps:}

- Below Fig. 3.1.4-5 a, b, c shows density of tweets. 

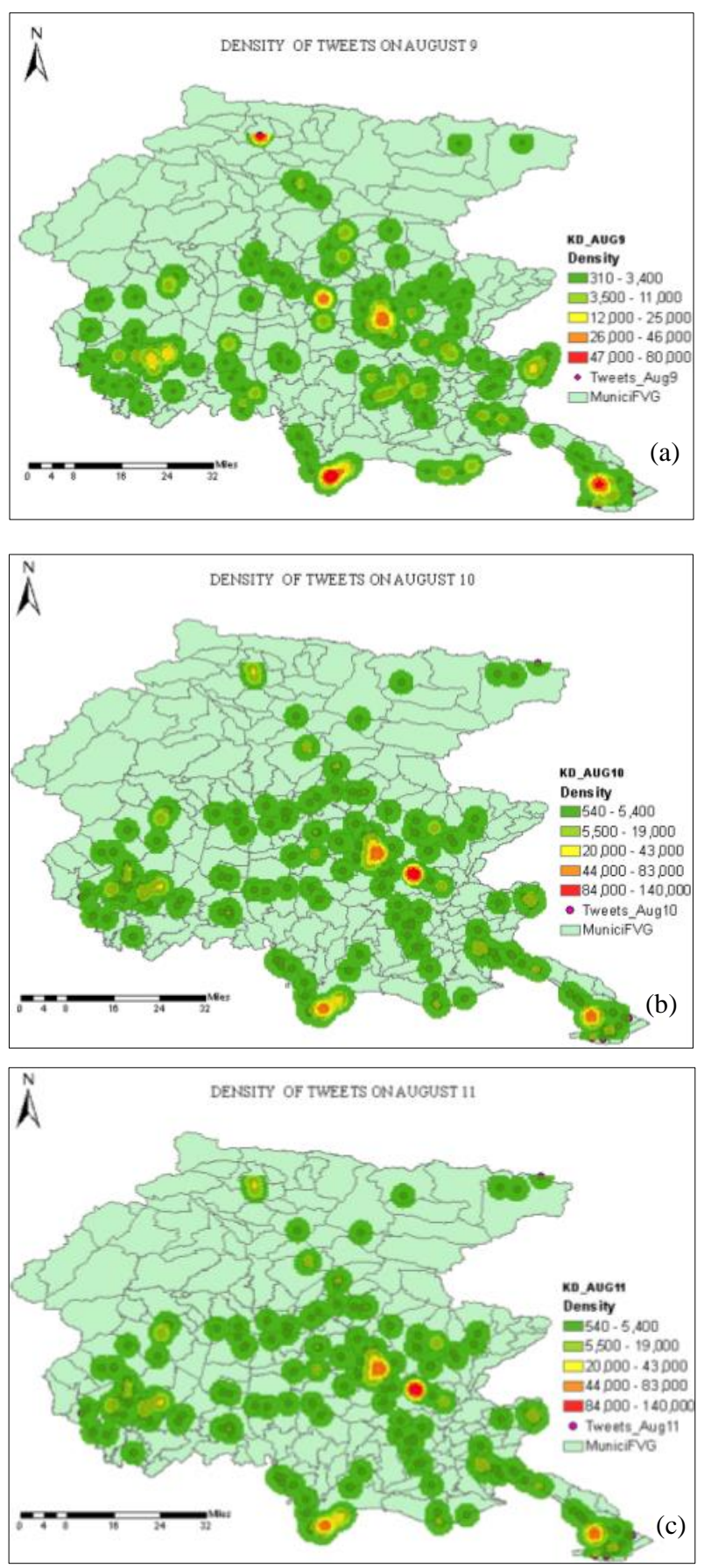

Figure 3.1.4-5 a, b, c Tweet Density on August 9, 10, 11

- $\quad$ Red color represent maximum tweet density and mostly related tweets in that place. Green - very less tweets and unrelated tweets. Yellow - tweets which are likely related to our scenario (Grado beach)

- $\quad$ Tweets are filtered based on date $9^{\text {th }}$ august16 and time, density of tweets are calculated. On very sunny day, tweets in Grado are from 540 to 5400, which show some tweets are happening and can be reliable as proxy for presence. Tweet density ranging from 47000 to 80000 are observed in Lignano and Trieste. 26000 to 46000 of tweet density are Udine, Pagnacco and Comeglians.

- On rainy day august 10 , density of 137560 is observed in Buttrio. In addition, density ranging from 44000 to 83000 are observed in Udine (73932), Lignano (59296), and Trieste (66260).
- On sunny day, highest density from 84000 to $1,40,000$ are observed in Buttrio. The other class values 44,000 to 83000 are observed in Udine, Trieste, and Lignano.

- Tweets density in other places are more than Grado due to various attractive scenery, museums, Church, Sundials, hiking, shopping malls and famous landmarks.

\subsection{FRUILI DOC:}

Friuli Doc is a wine and annual food event held in Udine since 1995. This event is organized by the city and held in the historical city centre for four days. It happens on 8 - 11 September. (FRIULI DOC, n.d.)This event consist of food, wine and craft stands. This event accompanied by various initiatives such as cooking classes, tasting, demonstrations and workshops, presentation and conferences focus on typical products, exhibitions, street

performances, educational workshops for children and music. To understand the presence of people in Udine during non-event and event day are selected ie., September 3, 4, 10 and 11 of 2016 between $6 \mathrm{pm}$ and $12 \mathrm{am}$ as it is peak moment of event.

- To know the number of individuals attending the event on September 10 and 112016 at $6 \mathrm{pm}$ and 12 am respectively.

- To know the number of individuals present in Friuli Venezia Giulia and Udine on September 3 and 42016 at 6pm and 12am respectively.

- Where are the people coming from? (From which municipality).

\subsubsection{Thematic Maps -Italians \& Foreigners:}

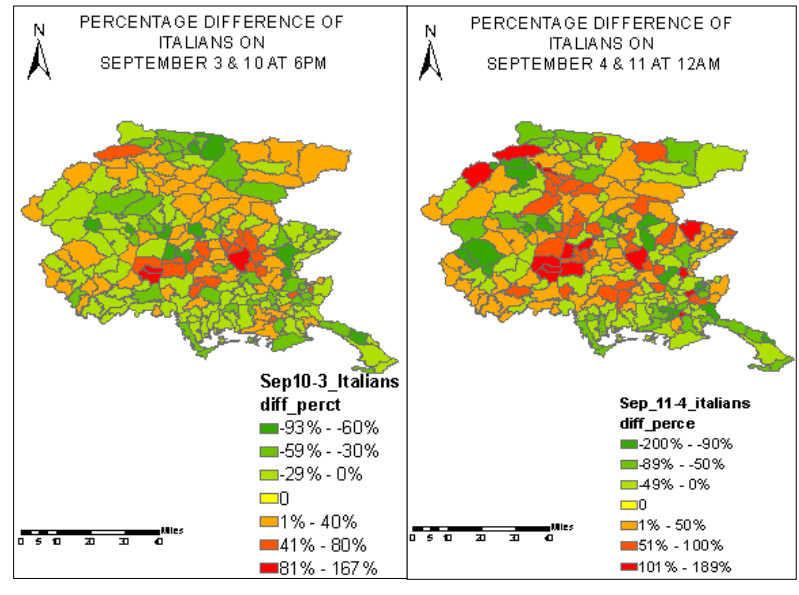

(a)

(b)

Figure 3.2.1-1(a) Presence of Italians on Sep 3 - 10 @ 6pm (b) Presence of Italians on Sep 4 - 11 @ 12 am

- The above fig 3.2.1-1 a \& b show presence of Italians per community wise. September 10 and 11 are event dates. $10^{\text {th }}$ evening $(6 \mathrm{pm})$ and next day $11^{\text {th }}$ early morning (12am) are considered to understand the presence on last day of the event. Week before event day i.e., September $3 \& 4$ (6pm \& $12 \mathrm{am})$ are considered to compare the presence on normal and event day presence difference.

- During Friuli doc event in Udine, Red zone represent presence of people on event day (10 $0^{\text {th }}$ september16) in municipality. Green zone represent presence of people on non-event day ( $3^{\text {rd }}$ september16) which is one week before.

- Event day - September $10^{\text {th }}$ at $6 \mathrm{pm}$, presence difference of 99\% noticed in Udine, which is more than presence on $3^{\text {rd }}$ 
September. While in Valvasone Arzene there is presence of $166 \%$, this place is famous for historic centre with elegant dwellings of fourteenth to seventeenth century.

- $\quad$ Places other than Udine, with noticeable presence difference such as SanMartino Al Tagliamento with percentage difference of $150 \%$. Prato Carnico (52\%), Mossa (46\%), Sedegliano (73\%), San Giorgio della Richinvelda (51\%), Flaibano (41\%), Mereto di tomba (44\%), Buttrio (67\%), Remanzacco (54\%), Povoletto (45\%), Reana Del Roiale (53\%), Tavagnacco (56 \%), Pagnacco (51\%), Fagagna $(31 \%)$.

- $\quad$ These places are famous for castle surrounding with moat and ancient city walls, ancient century theatre with rich paintings.

- Normal day, week before event day- September $3^{\text {rd }}$ at 6 pm, percentage difference in Udine is not noticeable when compared with event day. Other places than Udine, has more individual presence and better percentage difference in places like Pinazano al Tagliamento (93\%), Majano (69\%), Cividale di Rosazzo (66\%), Coseano (66\%), Dignano (77\%), Paularo (68\%), Treppo Carnico (69\%).

- Event day - early morning, September 11 at 12 midnight, Udine has $128 \%$ presence difference more than week before. It can be said that people are more on the last day of the event due to weekend.

- $\quad$ People presence with significant percentage difference apart from Udine is observed in Prato carnico (124\%), Mariano del Friuli (106\%), Forni di Sopra (115\%), Turriaco (188\%), Pulfero (132\%), Rive D'arcano (115\%), Sedegliano (101\%), San Martino Al Tagliamento (140\%), Valvasone Arzene (159\%).

- While on Non-event day, September 4 at 12 am, the presence difference is observed greater in Ampezzo (128\%), Sauris (200\%), Aviano (90\%), Budoia (103\%), Poberdo del lago (100\%), Ruda (107\%), Povoletto (95\%), Travesio (106\%), Nimis (127\%), Monrupino (127\%).

- The above mentioned places are famous for its landmarks, war left overs, sundials, hiking, historical places etc.,

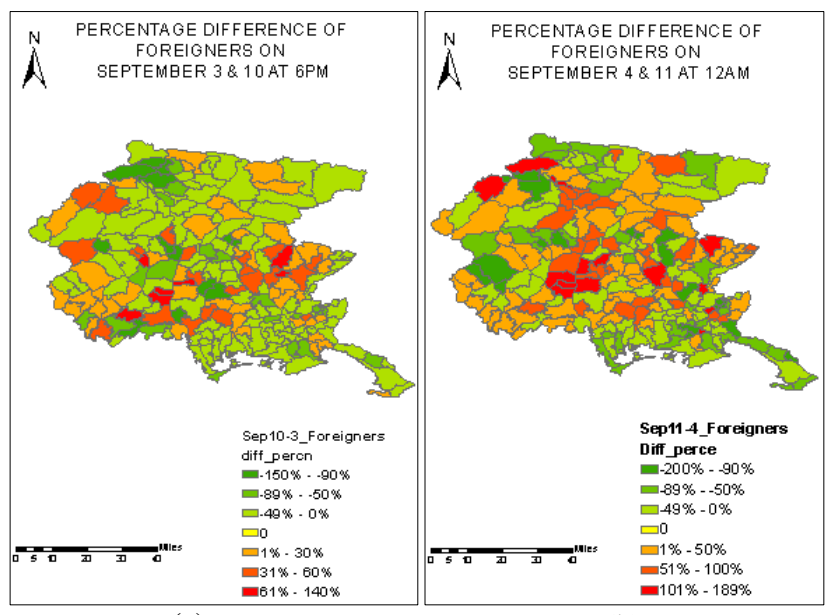

(a)

(b)

Figure 3.2.1-2 (a) Presence of Foreigners on Sep 3 - 10 @ 6pm (b) Presence of Foreigners on Sep 4 - 11 @ 12am

- The fig 3.2.1-2 a, b shown is percentage difference of foreigners in Friuli region on Friuli doc event September $10^{\text {th }}$ and $11^{\text {th }}$ in Udine and week before. i.e., September $3^{\text {rd }}$ and $10^{\text {th }} 2016$

- Event day $-10^{\text {th }}$ evening, the presence difference of foreigners in Udine is $36 \%$, which is less when compared with Italians presence difference.
- In other municipalities, the presence difference of foreigners is greater than presence in Udine during event day, may be discovering other tourist places.

- Normal day - week before event - September $3^{\text {rd }}$ at $6 \mathrm{pm}$, foreigners presence is increased in Friuli region. Places with higher percentage difference is noticed in Basiliano (138\%), Mereto di Tomba (122\%), Pinzano Al Tagliamento (116\%), Castelnovo del Friuli (94\%), Ovaro (118\%), Comeglians $(150 \%)$, Rigolato (117\%), Prato Carnico (134\%), Chions (142\%), Andreis (114\%).

- The b part of the map is the presence of foreigners at September $4^{\text {th }}$ and $11^{\text {th }}$ early morning $12 \mathrm{am}$.

- $\quad$ Event day - September 11 at 12 am, presence difference of $128 \%$ is observed in Udine, Which is greater than presence difference the before day.

- Places with considerable presence difference other than Udine is observed in Pulfero (132\%), Sedegliano (101\%), San Martino Al Tagliamento (140\%), Valvasone Arzene (159\%), Prato Carnico (124\%), Forni di Sopra (115\%), Corno Di Rasazzo (171\%), Turriaco (188\%), Mariano Del Friuli (106\%).

- Non-event day: September $4^{\text {th }}$ at $12 \mathrm{am}$, foreigners presence observed in Budoia (103\%), Ampezzo (128\%), Sauris $(200 \%)$, Travesio (106\%), Nimis (127\%), Artegna (122\%), Ruda (107\%).

- It can be assumed that, week before on $3^{\text {rd }}$ and $4^{\text {th }}$ September people are present in Budoia, Ampezzo etc., and they are moving to Udine surroundings to attend the event.

- The above points, explains how people interact with surrounding in two conditions (event and non-event day).

\subsubsection{Origin Destination Flows for Italians:}
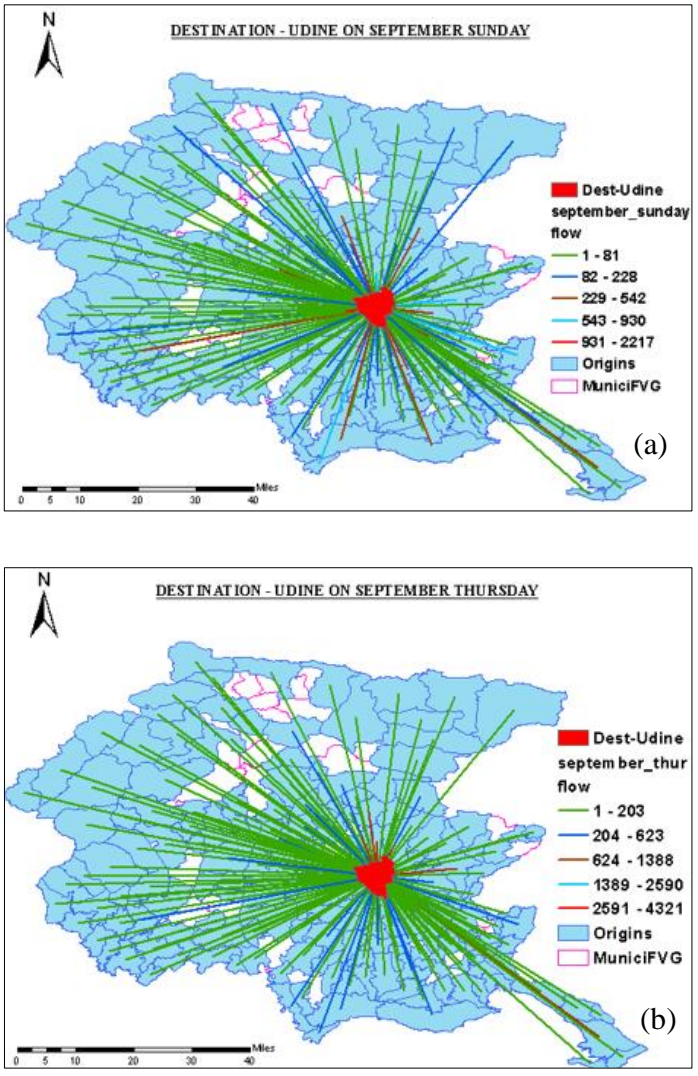

Figure 3.2.2-3 (a) \& (b) OD flows of Italians on September Sunday and Thursday 
- $\quad$ As per the above fig 3.2.2-3 a, b shows the flow of Italians to Udine from each municipality. The database is filtered by day and month wise due to absence of date and time. The above flow lines include all the flows happen on that particular day.

- The flow count is more on Thursday September16. The flow decreased on Sunday, may be people are staying in nearby hotels or in relative home.

- Flow count above 500 are from places which are near to Udine. Flow count from farthest places to Udine is in between $100-500$.

- The Italians present in the event are from all over the Friuli region and the flow to Udine is in thousands.

- The Italians flow in Friuli region on Thursday and Sunday is 4321 and 2217 respectively.

3.2.3 Origin Destination Flows for Foreigners:

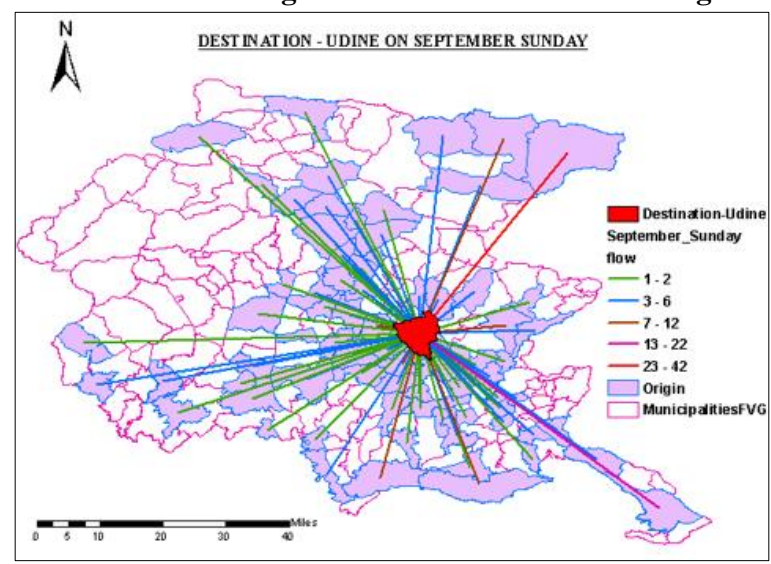

(a)

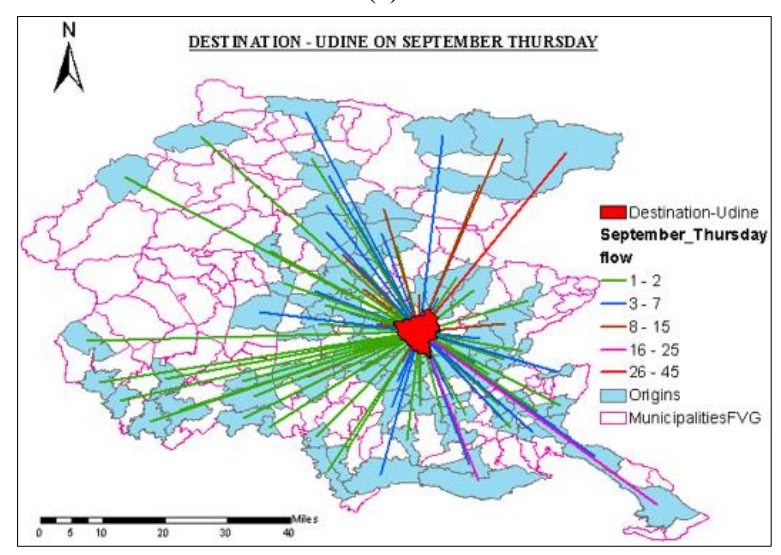

(b)

Figure 3.2.3- 4 (a) \& (b) OD flows on September Sunday and Thursday

- $\quad$ Above fig 3.2.3- $4 \mathrm{a} \& \mathrm{~b}$, show that Destination - event holding place Udine, Origin -municipalities where foreigners are travelling from.
- Foreigners flow count ranging from 1 to 42 are from places which are farthest to Udine. Flow is from very less number of places to Udine mostly from boundaries of Friuli. This may be due to foreigners have just flown into the country, may be travelling and staying for temporary reasons.

- Maximum flow count of people is observed from Treviso and Trieste. Treviso and Trieste consist of beautiful scenery and tourist places for outsiders.

\subsubsection{Tweet- Density Maps:}

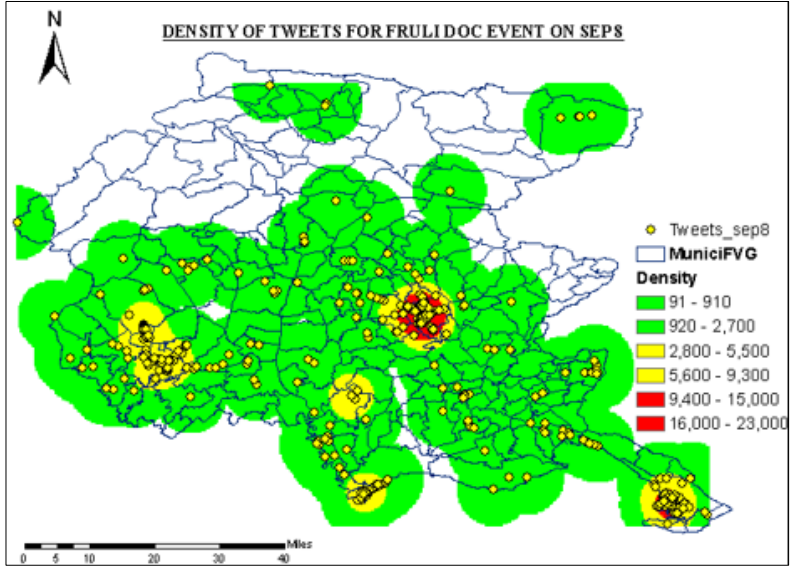

(a)

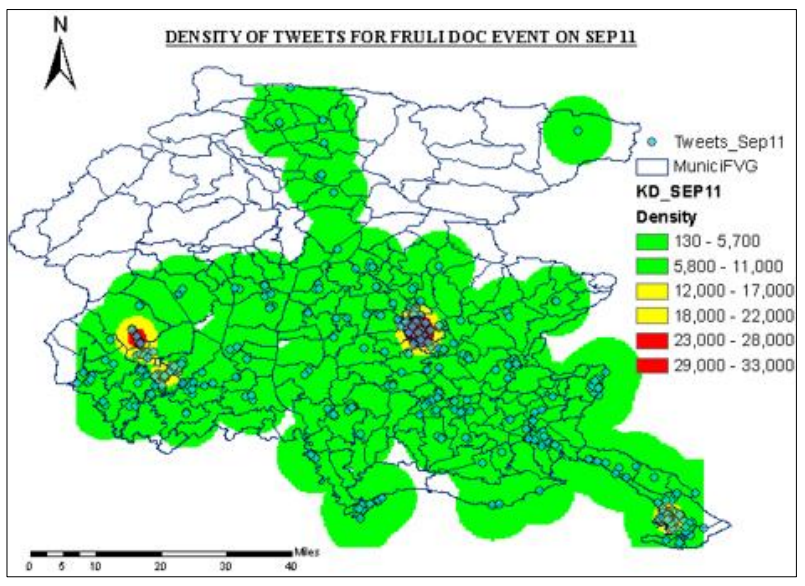

(b)

Figure 3.2.4-5 (a) \& (b) Tweet Density on September 8 and 11

- $\quad$ Above fig 3.2.4-5 a \& b show the density of tweets in Udine for event. Tweets are filtered based on location (Udine), date. For Friuli doc event first and last day of the event are considered to know the degree of tweets posting on social media regarding event.

- $\quad$ September $8^{\text {th }}$ and $10^{\text {th }}$ tweet feeds are selected and taken as inputs for above density maps.

- Red color represents density of tweets in Udine, yellow represents posting of tweets may related to event or may not 
be related to event. Green represents posting of general tweets not about event.

- Event day tweets - September 8, people per tweet feeds ranging from 16000 to 23000 are observed in Udine, 9400 to 15000 in Trieste, 2000 to 9000 tweets are observed in Pordenone and Lignano Sabbiadoro.

- The places are famous for resorts, spa, water sports, beach and scenery.

- $\quad$ Event last day - September 11, tweets ranging from 29000 to 33000 are observed in Udine and 23000 to 28000 are observed in Aviano. More tweets are observed in Udine on last day due to presence of local residence, foreigners and weekend.

\subsection{CANTINE APERTE:}

Cantine aperte is an open cellar, most important wine tourism event in Italy. This event occurs on last Sunday of May every year. May 27 and 28 since 1993 wineries, members of Movimento Turismo del Vino organize this event to personally meet the public. (Cantine Aperta, n.d.) It has become a philosophy and a way to travel and discover Italian wine territories, an increasing number of tourists, wine wonderers and wine lovers visiting this event every year hoping for unique experience. Open cellar mostly attracts young groups and couples who help sentient the countless culture, food and artistic initiatives. In 2016 event took place in Pordenone and Udine.

- To know the presence of people during non-event day, before one week of event and the day of the event - May $21^{\text {st }}$ and May $28^{\text {th }}$ of 2016 at $6 \mathrm{pm}$ respectively.

- Individuals from which municipality are visiting to event?

- To know any tweets posted on this day.

\subsubsection{Thematic Maps - Italians \& Foreigners:}

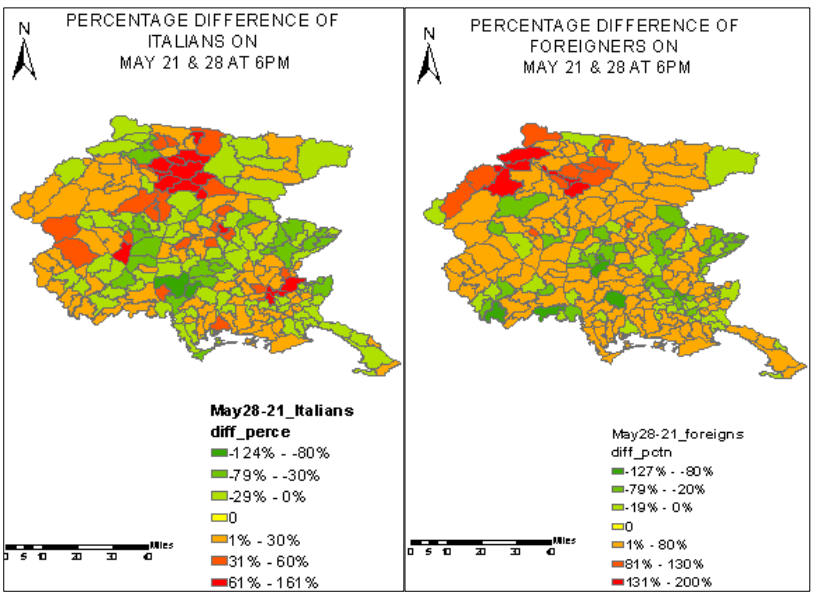

(a)

(b)

Fig 3.3.1-1 a \& b shows presence of both Italians and

Foreigners on May 21 and 28 at $6 \mathrm{pm}$.

- $\quad$ The above fig. 3.3.1-1 a \& b shows the presence difference of individuals on May 21st and 28th. Udine and Pordenone are event places for Cantine aperte event on May 28 at $6 \mathrm{pm}$
- Event day - May 28th, presence difference of 22\% are observed in Pordenone. Other places than Pordenone, significant presence difference are observed in Vivaro (74\%), Bordano (63\%), Amaro (75\%), Tolmezzo (104\%), Zuglio (87\%), Arta Terme (86\%), Ligosullo (115\%), Cormons (61\%), San Vito Al Torre (90\%).

- Non - event day: week before event, May 21 at $6 \mathrm{pm}$, presence difference of $17 \%$ is noticed in Udine.

- $\quad$ Places with presence difference higher than Udine, obseved in Bertiolo (123\%), Cividale Del Friuli (57\%), Ovaro (42\%), San Leonardo (54\%), Pulfero (43\%).

- These places famous for church, shopping malls, recreation centers and famous tourist places.

- In b part of the figure, Event day- May 28th at $6 \mathrm{pm}$, Foreigners presence difference in Udine and Pordenone is comparatively very low. This may be due to foreigners in May month are very less when compared to other seasons, no awareness of the event, etc.,

- Other than Pordenone, higher presence difference is observed in Verzegnis (170\%), Villa Santina (161\%), Raveo (200\%), Forni di Sotto (133\%), Sauris (200\%), and Prato Carnico (169\%).

- Non event day : week before event, May 21 at $6 \mathrm{pm}$, presence difference of $16 \%$ and $23 \%$ are observed in Udine and Pordenone. This is due to Udine with higher growth rate, famous shopping centers, etc.,

- In other municipality, significant presence difference is observed in places such as Merreto Di Tomba (127\%), San Vito Di Fagagna (114\%), pasiano di Pordenone (110\%), and Sesto Al Reghena (80\%).

\subsubsection{Origin Destination Flows for Italians:}

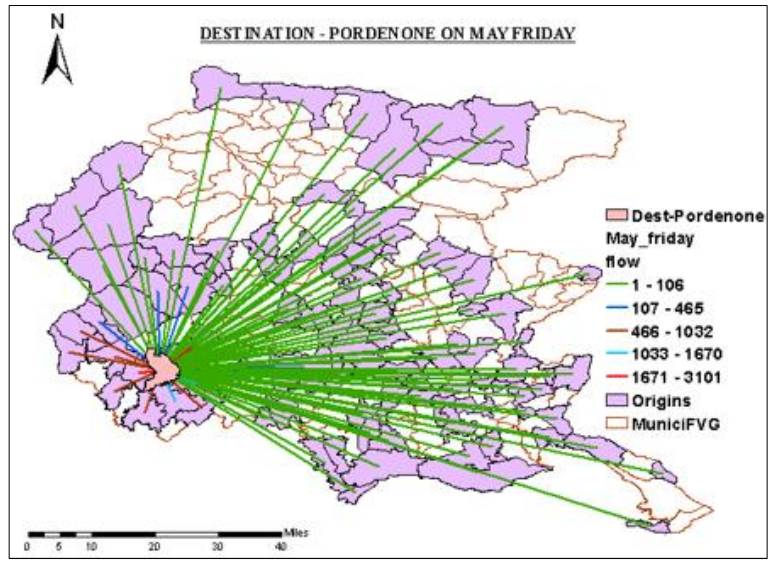

(a) 


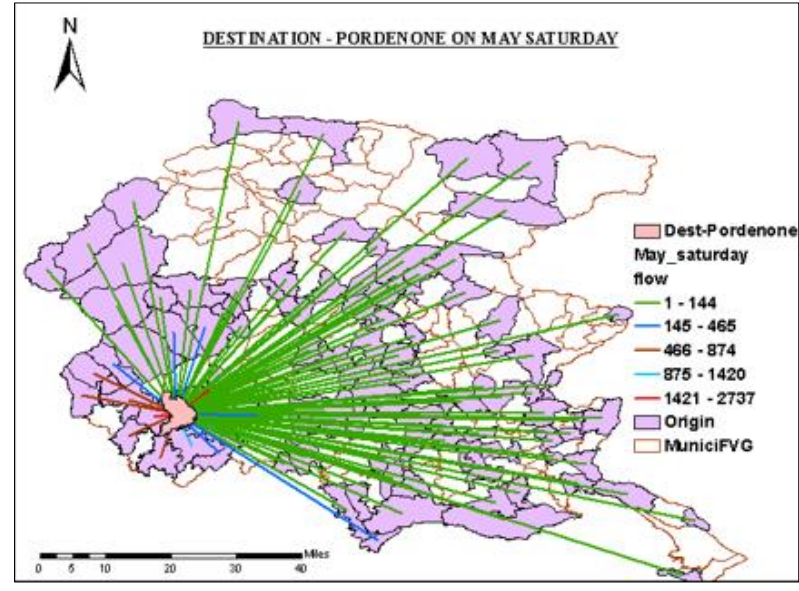

(b)

Figure 3.3.2-2 (a) \& (b) OD flows of Italians on May Friday and Saturday

- $\quad$ The above fig 3.3.2-2 a \& b explains the flow count of Italians to Pordenone. The event days May 27 and 28 are Friday and Saturday of the month. OD matrices are filtered based on destination - Pordenone. Count flow of people to the event are from East part of Friuli region.

- Flow count ranging from 1400 to 3000 are observed from nearby places to event. Flows from 1 to 100 are wide spread and are mostly from all the municipalities. Count is less due to distance from the origins to destination is farthest, may be less transport service etc.,

\subsubsection{Origin Destination Flows for Foreigners:}

- The below fig 3.3.3-3 a \& b explains inflow movement of people to destination. The event days May 27 and 28 are Friday and Saturday of the month.

- The flow count of foreigners on May Friday and Saturday are less when compared to flow count of Italians.

Municipalities from where foreigners are flowing to the event are Pontebba, Cividale Del Friuli, Duino Aurisina, Doberdo Del Lago, Latisana, Ronchis, Codroipo, San Giorgio Della Rinchinvelda, Spilimbergo, Dignano, Andreis, Polcenigo, Sacile, Pasiano Di Pordenone.

- $\quad$ Flow count from west part of Friuli are comparitvely more in number than flow count from east part.

- This may be due to foreigners are staying in that municipality and moving to other place the next day, visiting tourist places, visiting relatives home, etc.,

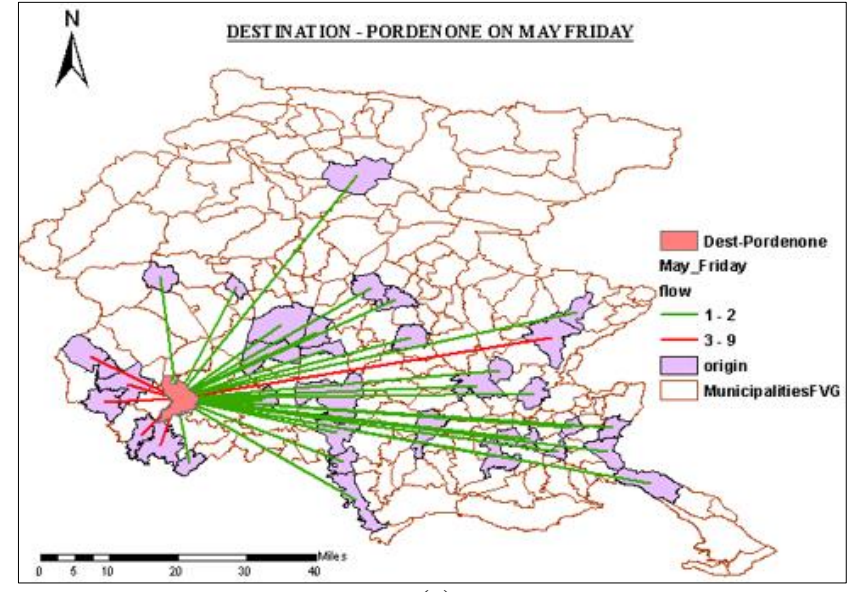

(a)

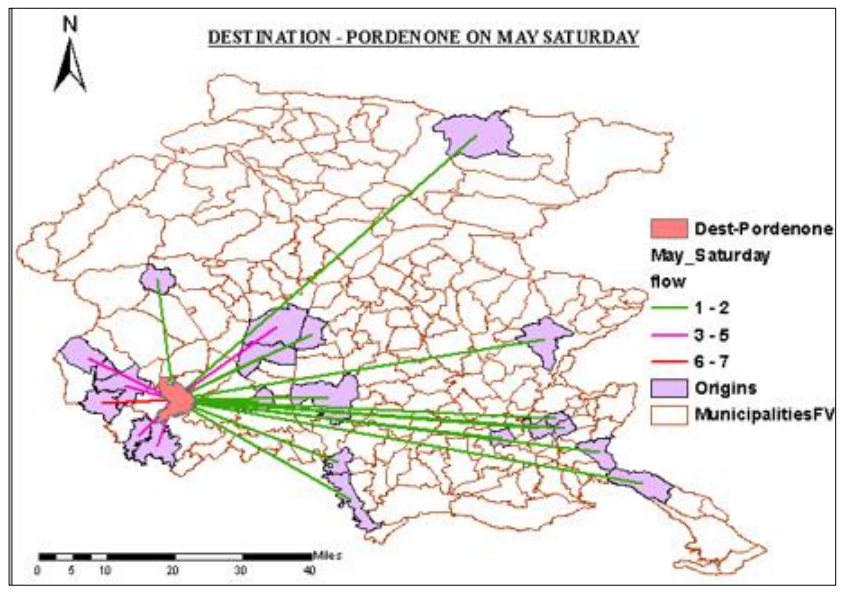

(b)

Figure 3.3.3-3 (a) \& (b) OD flows of Foreigners on May Friday and Saturday

\subsubsection{Tweet-Density Maps:}

- The below fig. 3.3.4- 4 a \& b show Density of Tweets calculated to understand presence of people in Pordenone with the help of social media tweets.

- $\quad$ Tweet feeds are filtered based on date and location. Tweet feed of May 27 and 28 of pordenone, used to calculate Kernel Density.

- $\quad$ Event day - May27th, it proves that people are present in Pordenone and Udine; social activity is also high.

- Density of tweets on May 27th in Pordenone and Udine, 6000 to 8000 are observed, may be due to high presence of young people, local residents and foreigners.

- $\quad$ Trieste and Lignano Sabbiadoro has 4000 to 6000 tweets, where famous beach, spa, water games, restaurants, musical hub etc.,

- $\quad$ Event second day - May 28, it shows that tweets are mostly from Udine and Pordenone. 
- Tweet density class from 12000 to 15000 , observed in Udine and Pordenone are very high, when compared with first day of event.

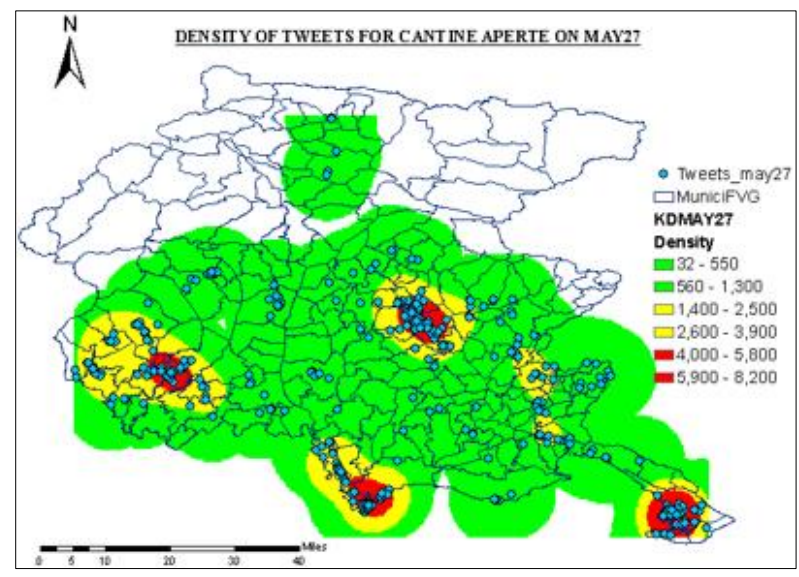

(a)

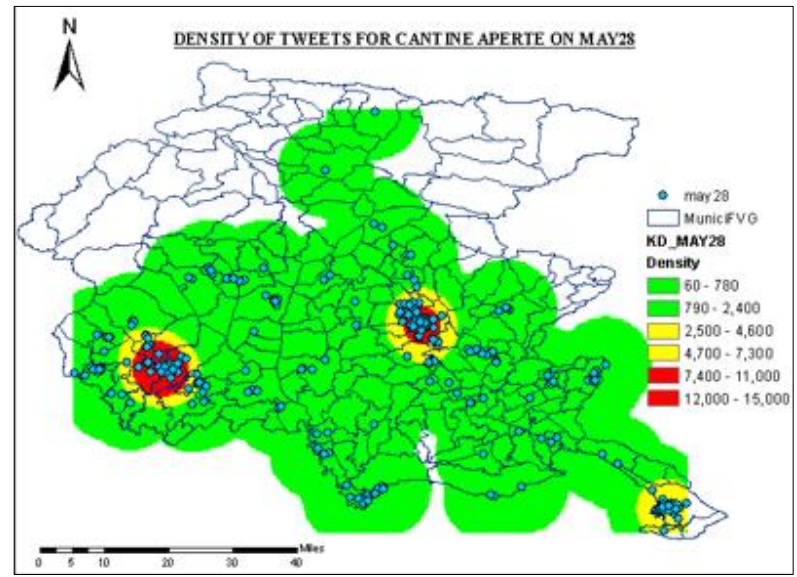

(b)

Figure 3.3.4-4 (a) \& (b) Tweet Density on May 27 and 28

- The above points are helpful in determining people presence with help of social media activity.

\section{CONCLUSION}

The case studies, opted in this study, take place in some or the other way in our day to day activity. These various conditions and scenarios help in analyzing individual presence and association with their surroundings activities. Geolocated cellular and twitter data is used to determine people presence, movements and number of flows happening between places with help of QGIS. The conditions considered in this study, were helpful in answering the above stated research questions.

\section{Acknowledgements}

I heartfully thank Prof. Salvatore Amaduzzi, Professor, Udine University, Italy for supporting, guiding and monitoring through the study period. I also convey my gratitude and thanks to Ms. Darshana Rawal, Assistant professor, CEPT University, India.

\section{REFERENCES}

i.

ii. IEEE, 2011 "International conference on Automation Science and Engineering" .

iii. ESRI, Arcgis Desktop help. (s.d.).

iv. Shamanth Kumar, Fred Morstatter, Huan Liu, 2013. "Twitter Data Analytics".

v. Rein Ahas, Jimmy Armoogum, Siim Esko, 2014. "Feasibility study on the use of mobile positioning data for tourism statistics".

vi. Wikipedia, 2017. "Information on Cellular network".

https://en.wikipedia.org/wiki/Cellular_network

vii. Wikipedia, 2017. "Information on Italy and its region". https://en.wikipedia.org/wiki/Italy

viii. Wikipedia, 2017. "Information on Friuli Venezia Guila". https://en.wikipedia.org/wiki/Friuli.

ix. Wikipedia, 2017. "Information on Algorithm and its work flow" https://en.wikipedia.org/wiki/Algorithm

x. Miloslava Plachkinova, A. V. (2016). "A conceptual framework for quality healthcare accessibilty: a scalable approach for big data technologies".

xi. Rashidi, "Utilising location based social media".

xii. "Twitter" 2017. "Twitter Api standards" https://developer.twitter.com/en/docs/tweets/search/ api-reference/get-search-tweets.html

xiii. Wikipedia, 2017. "Information on Friuli Doc event " http://www.friuli-doc.it/en/

xiv. Wikipedia, 2017. "Information on Grado beach" http://www.grado.info/en/

xv. Wikipedia, 2017. "Information on Cantine Aperta " 